\title{
Can physical activity influence the effect of the COVID-19 vaccine on older adults?
}

\section{A atividade física pode influenciar no efeito da vacina para COVID-19 em idosos?}

Francisco José Gondim Pitanga ${ }^{1}$

(D) https://orcid.org/0000-0002-1033-8684

Cristiano Penas Seara Pitanga ${ }^{2}$

(D) https://orcid.org/0000-0001-8276-3738

Carmem Cristina Beck ${ }^{3}$

(D) https://orcid.org/0000-0002-9429-9140

Abstract - Studies have shown reductions in the immune response capacity with the aging process (immunosenescence). Lifestyle factors (physical activity and diet) have been investigated as possible adjuvants to improve the effect of vaccines on the immune system in the elderly. The aim of this opinion article is to analyze studies on physical activity and the effect of influenza vaccines in an attempt to suggest that their results can also be found in future studies on physical activity and vaccines against COVID-19. Considering the results of the studies analyzed, it could be suggested that the practice of physical activity improves responses to the influenza vaccine. Thus, it could be assumed that, when transferring these findings to COVID-19, the importance of regular physical activity in the specific elderly population becomes extremely relevant during the COVID-19 pandemic.

Key words: Aged; COVID-19; Motor activity; Physical activity; Vaccine-preventable diseases.

Resumo - Estudos tem demonstrado reduçôes na capacidade de resposta imune com o processo do envelhecimento (imunosenescência). Fatores de estilo de vida (atividade física e dieta) começaram a ser investigados como possiveis coadjuvantes para melhorar o efeito das vacinas sobre o sistema imunológico em idosos. O objetivo deste artigo de opinião é analisar os estudos sobre atividade física e o efeito de vacinas contra a influenza, na tentativa de sugerir que os seus resultados possam ser encontrados, também, em futuras pesquisas sobre atividade física e vacinas contra o COVID-19. Considerando os resultados dos trabalhos analisados, pode-se sugerir que a prática de atividade física melhora as respostas à vacina contra a influenza. Desta forma, pode-se supor, que ao se fazer a transferência destes achados para o COVID-19, a importância da prática regular da atividade física na população especifica de idosos passa a ser extremamente relevante durante a atual pandemia.

Palavras-chave: Atividade física; Atividade motora; COVID-19; Doenças preveniveis por vacina; Idoso.
1 Federal University of Bahia. Salvador BA. Brazil.

2 Catholic University of Salvador. Salvador BA. Brazil.

3 Federal Institute of Santa Catarina. Palhoça, SC. Brazil.

Received: August 19, 2020 Accepted: October 09, 2020

How to cite this article Pitanga FJG, Pitanga CPS, Beck CC. Can physical activity influence the effect of the COVID-19 vaccine on older adults? Rev Bras Cineantropom Desempenho Hum 2020, 22:e76586. D0l: http://dx.doi. org/10.1590/1980-0037.2020v22 e76586

Copyright: This work is licensed under a Creative Commons Attribution 4.0 International License. 


\section{INTRODUCTION}

Since the recognition, in March 2020, of the pandemic status by the World Health Organization (WHO), the new coronavirus has continued to infect people and cause deaths. Up to 10/9/2020, 36,361,054 accumulated cases and 1,056,186 deaths were recorded worldwide ${ }^{1}$.

Thus, there is consensus in the scientific community about the urgency in the production of vaccines against COVID-19 which are safe, effective and quickly made available to the population in order to mitigate the consequences of the pandemic and protect against future outbreaks. Traditionally, vaccine development progresses from pre-clinical studies, passing through the three clinical phases and ending with licensing for large-scale production. In the context of the current pandemic, schedules are being shortened by overlapping stages and phases with the aim of speeding up the process so that the population can be immunized with vaccines ${ }^{2}$.

Studies have shown reductions in the immune response capacity with the aging process (immunosenescence), as well as reduced immunization against influenza, with advancing age. Lifestyle factors (physical activity and diet) began to be investigated as possible adjuvants to improve the effect of vaccines on the immune system in the elderly ${ }^{3-5}$.

In this sense, in a study carried out with 160 older adults, it was found that participants randomized to the cardiovascular exercise group experienced improvements in seroprotection throughout the influenza season ${ }^{6}$. More recently, a study carried out with older women demonstrated better immunological results after influenza vaccination in those more physically active ${ }^{7}$.

Thus, with the availability of the vaccine, when transferring the results of studies on physical activity and immunization against influenza to COVID-19, it could be assumed that older adults may have less capacity in the immune response, highlighting the knowledge that even with the vaccine, the practice of physical activity is one of the strategies to mitigate the effects of the pandemic.

Specifically with regard to physical activity and COVID-19, several points of view have been published emphasizing the importance of the practice of physical activity during the pandemic and the importance of government officials to recognize outdoor physical activity as essential, in addition to the suggestion of more aggressive public policies to make the population more physically active as a means of coping with the current and future pandemics with similar characteristics ${ }^{8-10}$.

Thus, the aim of this point of view is to analyze studies on physical activity and the effect of vaccines against influenza, in an attempt to suggest that their results could also be found in future studies on physical activity and vaccines against COVID- 19.

\section{STUDIES ON PHYSICAL ACTIVITY AND THE EFFECT OF VACCINES AGAINST INFLUENZA AND H1N1}

One of the first studies on the influence of physical activity on influenza 
vaccine was carried out in 2002. In this work, the authors aimed to test the hypothesis that physical exercise would be associated with better immune response specific to influenza after vaccination in 56 older adults, who were interviewed by phone to classify their levels of physical activity. Subsequently, all participants were immunized with the trivalent vaccine against types $A$ and B influenza and were followed for approximately 7 months. Among other results, physical activity was associated with in vitro improvement in the proliferation of influenza vaccine. In addition, specific anti-influenza antibodies ( $\operatorname{IgM}$ and $\operatorname{IgG}$ ) were higher in active participants compared to moderately active and sedentary participants, as well as greater proliferation of influenza-specific lymphocytes in active individuals than in sedentary ones. The authors concluded that regular physical activity can contribute to better response to influenza immunization in the elderly.

Subsequently, in 2003, a new study aimed to determine the effect of physical activity on the production of specific antibodies in response to the 1998-99 flu virus vaccine. Thirty older adults participated in the analysis, whose physical activity was evaluated using the Physical Activity Scale for the elderly. Subsequently, plasma samples were collected before, 1, 2,4 and 6 weeks after vaccination against the influenza virus. The main results showed increase in specific antibodies after 6 weeks of vaccine application, with positive correlation between physical activity and these antibodies, indicating better immune response among the most physically active subjects.

In 2004, researchers tested the hypothesis that the effectiveness of the flu vaccine is reduced in adults over 65 years and physically inactive. The study included 27 adults over 64 years of age who were allocated to exercise group and control group. Individuals were immunized with trivalent influenza vaccine before and after exercise intervention. After exercise intervention, participants exhibited increase in antibodies to influenza $\mathrm{A}$ (H1N1) when compared to controls. The authors suggested that exercise may improve the response to influenza immunization.

In 2009, scientists sought to identify whether training with cardiovascular exercises would result in improved antibody responses to influenza vaccination in 140 older adults with mean age of 69.9 years, who were randomized and followed up for 10 months. The intervention consisted of moderate cardiovascular exercise (60-70\% of maximum oxygen uptake) compared to flexibility and balance training after the influenza vaccine. The main result found was that the cardiovascular exercise group showed significant increase in seroprotection 24 weeks after vaccination, while the flexibility training group did not show significant changes. The authors concluded that randomized participants for cardiovascular exercise experienced improvements in seroprotection throughout the flu season, confirming the hypothesis that regular exercise improves responses to influenza vaccine.

More recently, in 2019, a group of Singaporean researchers endorsed previously obtained findings, when 56 older women were submitted to the use of accelerometer for 14 days after influenza vaccine. Subsequently, they 
analyzed the immune responses to the vaccine according to the number of daily steps of these women. The main results found were: individuals who walked more had greater post-vaccine expansion of monocytes and plasma blasts in the peripheral blood. Participants who were more physically active also demonstrated positive regulation of genes associated with monocyte/ macrophage phagocytosis. They also observed that active women showed greater induction of antibodies against influenza B. They concluded that the results are consistent with better immunological condition in those who are more physically active.

\section{CONCLUSION}

Based on the results of studies on physical activity and immunization against influenza in the elderly, it could be concluded that, when transferring these findings to COVID-19, the importance of regular practice of physical activity in this specific population becomes extremely relevant, especially when guided by Physical Education professionals. In this sense, older adults should maintain a routine of regular physical exercises considering that, even after being vaccinated, the effects may not be as expected regarding the duration and magnitude of the immunization if they are physically inactive. The regular practice of physical activity seems to cause more significant immune responses due to the influenza vaccine and when we extend these results to COVID-19, the importance of more aggressive public policies by government agencies is justified, so that this population becomes more physically active. As soon as the vaccine against COVID-19 is available to the population, new studies are suggested to test the hypothesis that physical activity can improve the immune responses of the vaccine against COVID-19 in the elderly.

\section{COMPLIANCE WITH ETHICAL STANDARDS}

\section{Funding}

This research did not receive any specific grant from funding agencies in the public, commercial, or no-profit sectors. This study was funded by the authors

\section{Ethical approval}

This research is in accordance with the standards set by the Declaration of Helsinki

\section{Conflict of interest statement}

The authors have no conflict of interests to declare.

\section{Author Contributions}

Conceived and designed the experiments: FJGP. Performed the experiments: NSA. Analyzed data: NSA. Contributed reagents/materials/analysis tools: NSA. Wrote the paper: FJGP; CCB; CPSP. 


\section{REFERENCES}

1. World Health Organization. Novel Coronavirus (2019-nCoV). Available at: https://www.who.int/ [accessed 09.10.2020].

2. Deming ME, Michael NL, Robb M, Cohen MS, Neuzil KM. Accelerating Development of SARS-CoV-2 Vaccines - The Role for Controlled Human Infection Models [published online ahead of print, 2020 Jul 1]. N Engl J Med 2020;383(10):e63.

3. Kohut ML, Cooper MM, Nickolaus MS, Russell DR, Cunnick JE. Exercise and psychosocial factors modulate immunity to influenza vaccine in elderly individuals. J Gerontol A Biol Sci Med Sci 2002; 57 (9): M557-M562.

4. Schuler PB, Leblanc PA, Marzilli TS. Effect of physical activity on the production of specific antibody in response to the 1998-99 influenza virus vaccine in older adults. J Sports Med Phys Fitness 2003;43(3):404.

5. Kohut ML, Arntson BA, Lee W, Rozeboom K, Yoon KJ, CunnickJE, McElhaney J. Moderate exercise improves antibody response to influenza immunization in older adults. Vaccine 2004; 22(17-18):2298-2306.

6. Woods JA, Keylock KT, Lowder T, Vieira VJ, Zelkovich W, Dumich S, et al. Cardiovascular exercise training extends influenza vaccine seroprotection in sedentary older adults: the immune function intervention trial. J Am Geriatr Soc 2009;57(12):2183-91.

7. Wong GCL, Narang V, Lu Y, Camous X, Nyunt MSZ, Carre C, et al. Hallmarks of improved immunological responses in the vaccination of more physically active elderly females. Exerc Immunol Rev 2019; 25:20-33.

8. Pitanga FJG, Beck, CC, Pitanga CPS. Atividade física e redução do comportamento sedentário durante a pandemia do Coronavírus. Arq Bras Cardiol 2020; 114(6): 1058-1060.

9. Pitanga FJG, Beck, CC, Pitanga CPS. Should physical activity be considered essential activity during the covid-19 pandemic? Int J Cardiovasc Sci 2020; 33(4): 401-403.

10. Pitanga, FJG, Beck CC, Pitanga CPS. Inatividade física obesidade e COVID-19: perspectivas entre múltiplas pandemias. Rev Bras Ativ Fís Saúde 2020; 25: e0114.

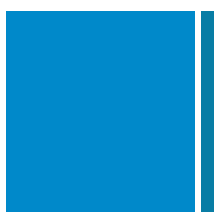

Corresponding author

Francisco José Gondim Pitanga

Faculdade de Educação - Universidade Federal da Bahia.

Av. Reitor Miguel Calmon, s/n - Vale do Canela, Salvador, Bahia, Brasil.

CEP: $40.000-00$

Email: pitanga@lognet.com.br 